\title{
Platônicos, aristotélicos ou sexistas? A metafísica implícita nas concepções geométricas associadas à produção de corações artificiais ${ }^{1}$
}

\author{
Platonists, Aristotelians, or sexists? The implicit metaphysics \\ in geometrical conceptions associated to the production of \\ artificial hearts
}

MARISOL MARINI
Universidade de São Paulo | USP

RESUMO O intuito é explorar as concepções matemáticas da natureza, a compreensão de que o suposto mundo natural manifesta-se por meio de códigos matemáticos, investigando os ecos desses argumentos na produção de dispositivos de assistência circulatória, chamados de corações artificiais. O ponto de partida é uma situação relativa ao exame de qualificação e resultados de pesquisa de uma das bioengenheiras da rede investigada, cuja tese justifica matematicamente a correlação entre o desenho das aletas (pás que fazem o rotor do dispositivo girar) a uma constante real algébrica extraída da Sequência de Fibonacci, conhecida também como proporção áurea ou divina. Trata-se de iluminar uma possível relação entre temáticas metafísicas associadas à perfeição, harmonia e beleza e o papel da feminilidade e a presença de mulheres na bioengenharia. O propósito não é reificar, naturalizar ou generalizar posições de gênero, mas explorar o papel estratégico da presença feminina num campo tido como masculino. Recuperando argumentos de Alexandre Koyré e dialogando com a hipótese de Edwin Burtt a respeito das bases metafísicas da ciência moderna o intuito é problematizar a emergência de argumentos metafísicos, a despeito do esforço de purificação construído ao longo de toda a história das ciências modernas e do desenvolvimento tecnológico.

Palavras-chave coração artificial - antropologia da ciência e da tecnologia - gênero e tecnociência - metafísica - proporção áurea.

\begin{abstract}
Our aim is to explore mathematical conceptions of nature, the assumption that the supposedly natural world manifests itself through mathematical codes, investigating the echoes of these arguments in the production of circulatory assistant devices, called artificial hearts. The starting point is a situation related to the doctoral candidacy examination and research process of one of the bioengineers of the network, whose thesis justifies mathematically the correlation between the design of the rotor blades of the device to a real algebraic constant drawn from the Fibonacci sequence, also known as golden or divine proportion. It is a matter of illuminating a possible relationship between metaphysical themes associated with perfection, harmony and beauty with the role of femininity and the presence of women in bioengineering. The purpose is not to reify, naturalize, or generalize gender positions, but to explore the strategic role of the female presence in a field considered masculine. Recovering Alexandre Koyré's arguments and establishing a dialogue with Edwin Burtt's hypothesis about the metaphysical bases of modern science, the aim is to problematize the emergence of metaphysical arguments, despite the effort of purification that can be seen operating throughout the history of the modern sciences and technological development.
\end{abstract}

Keywords artificial heart - anthropology of science and technology - gender and technoscience-metaphysics - golden ratio. 


\section{Introdução}

A reflexão aqui proposta poderia ter como subtítulo: uma modesta investigação sobre as concepções de beleza, simplicidade e perfeição na produção de corações artificiais. ${ }^{2}$ Tratam-se de temáticas associadas a uma concepção metafísica que emerge junto às concepções geométricas que informaram o desenvolvimento dos desenhos de aletas, pás acopladas ao motor de um dispositivo de assistência circulatória, no âmbito de um projeto realizado em uma instituição paulista especializada em cardiologia.

Destaco o caráter modesto da investigação, uma vez que a concepção matemática da natureza, a emergência da metafísica nos campos supostamente purificados da produção científica e as questões de gênero na tecnociência são todos, por si só, grandes tópicos de investigação do pensamento social e do conhecimento científico. 0 propósito, no entanto, é partir de um caso etnográfico que permitirá articulá-los e investigar suas relações, evidenciando os modos como a geometria e a matemática desenvolvidas no campo de produção de tecnologias médicas articula problemáticas técnicas, morais e estéticas.

Partindo dos desdobramentos relativos ao exame de qualificação de uma pesquisadora da bioengenharia da rede investigada em minha pesquisa de doutorado, busco evidenciar o entrelaçamento de problemáticas associadas ao manejo da matemática e da geometria a concepções metafísicas.. A tese em questão justifica matematicamente a correlação entre o desenho das aletas (pás que fazem o rotor projetado para o dispositivo de assistência circulatória girar) a uma constante real algébrica extraída da Sequência de Fibonacci, conhecida também como proporção áurea ou divina. Trata-se de uma medida cercada de misticismo, definida como a razão de ouro que representa a mais agradável proporção entre duas medidas. A hipótese é a de que a sugestão de incorporar uma proporção associada a atributos subjetivos, à beleza e perfeição foi feita a uma mulher não por acaso. 0 intuito, no entanto, não é reificar, naturalizar ou generalizar posições de gênero, mas explorar o papel estratégico da presença feminina num campo tido como masculino, possibilitando a emergência de abordagens de certa forma consideradas acessórias.

Não é novidade, mas fato numericamente conhecido, a ausência de mulheres ou sua baixa representatividade nas carreiras de engenharia no Brasil e em boa parte das comunidades acadêmicas ainda hoje. ${ }^{4}$ Esta é também a realidade no campo de produção de corações artificiais e tecnologias de assistência circulatória na rede de instituições paulistas acompanhadas no escopo da pesquisa de doutorado realizada entre os anos de 2013 a 2018. 5 esta não é uma especificidade local. A antropóloga americana Lesley Sharp denuncia a escassez de mulheres no campo da produção de órgãos artificiais nos Estados Unidos, ${ }^{\circ}$ bem como a existência de uma estética moral nas representações de corpos que favorece formas genéricas (andróginas) ou corpos masculinos (na maioria das vezes saudáveis, atléticos e, em alguns casos, militarizados), que são apresentados como universais. - ${ }^{\mathrm{E}}$ curioso, no entanto, como alinhada à baixa representatividade das mulheres há uma percepção do campo específico da bioengenharia como de certa forma "feminina" frente às outras engenharias tradicionais, "verdadeiras", como destaca uma das poucas interlocutoras mulheres de Sharp:

Engenharia tem tudo a ver com se dar bem com os 'Old Boys'. Como mulher, eles encontrarão uma maneira de dizer a você: 'Você não é uma engenheira de verdade, não sabe ensinar design'... as mulheres são melhores nas "habilidades leves' (...), as mulheres são boas em escrever, articular, negociar e resolver problemas, colaborando. Mas estas são vistas como habilidades secundárias. A questão é realmente ser capaz de fazer o protótipo. Na [engenharia tradicional] trata-se de fundamentos versus materiais, design aplicado, fabricação de produtos... Você não pode começar na bioengenharia e ter credibilidade - 'bio' é 'suave' demais para ser considerado 'verdadeiro', isto é, engenharia clássica. ${ }^{\stackrel{B}{ }}$

Tal pesquisadora é descrita por Sharp como uma anomalia no campo, não só por ser uma das poucas mulheres, mas por reconhecer, em suas explicações sobre o coração, o corpo como um enigma, e não apenas como estrutura, forma e função. Ao abordar a estrutura adaptativa do órgão, impossível de ser replicada (ao menos até o momento), a bioengenheira destaca que tentar compreender o coração apenas pela sua função é um equívoco. Ela destaca 0 
modo único e complexo por meio do qual a natureza decidiu otimizar o órgão - embora considere que o órgão não tem 0 melhor design, já que apresenta falhas. A bioengenheira argumentava que era preciso reconhecer 0 coração das emoções ("heart of emotions"), embora este aspecto pudesse ser compartimentalizado - que era como ela operava na sua prática, buscando distinguir os aspectos entendidos como filosóficos dos pragmáticos. Ao contrário dos outros engenheiros, destaca Sharp, sua descrição não termina no modelo da falha, reconhecendo uma complexidade e a natureza caótica e complexa do órgão/corpo.

Na rede que acompanhei ao longo do trabalho etnográfico constatei não só que as mulheres não estavam proporcionalmente presentes, como ocupavam posições marginais nesse campo. Se perguntássemos a qualquer um dos pesquisadores daquelas instituições, eles provavelmente nos diriam que as mulheres eram fundamentais no campo e figuras importantes na condução das atividades dos laboratórios. Suponho, no entanto, que a importância associada às mulheres diz respeito sobretudo às suas atuações como "secretárias", dado o envolvimento delas na organização e nas tarefas pragmáticas. Apesar de nas relações interpessoais estabelecerem dinâmicas aparentemente horizontalizadas, não era difícil perceber uma complexa e ambígua hostilidade - estrutural e velada - quando observadas as posições que as mulheres ocupavam, sua representatividade em palestras, conferências em congressos, ou quantas delas alcançavam cargos de professoras. $\stackrel{9}{ }$

A reflexão que proponho aqui, no entanto, está menos interessada no caráter sociológico ou estatístico da problemática de gênero, mas sim pretende investigar a posição estratégica da "feminilidade"10 e a presença de mulheres num campo marcado por um formalismo conceitual rígido, um tecnicismo em que as discussões consideradas acessórias ao pragmatismo relacionado à produção de tecnologias são reservadas aos anexos das teses e trabalhos acadêmicos. As aspas na feminilidade servem justamente para suspender o sentido imediato do termo, que pretendo explorar ao longo da reflexão. A posição estratégica é profundamente paradoxal e complexa, como veremos.

Analisarei aqui uma das teses desenvolvidas enquanto eu realizava a pesquisa etnográfica, a única defendida por uma mulher no laboratório de bioengenharia naquele período. A candidata foi reprovada no exame de qualificação, algo pouco usual, para não dizer inédito. Além dos ajustes e redirecionamento da pesquisa, os membros da banca sugeriram que ela justificasse matematicamente a escolha do desenho das aletas da bomba de assistência circulatória que ela projetava à proporção áurea - definida por ela como a razão de ouro que representa a mais agradável proporção entre duas medidas.
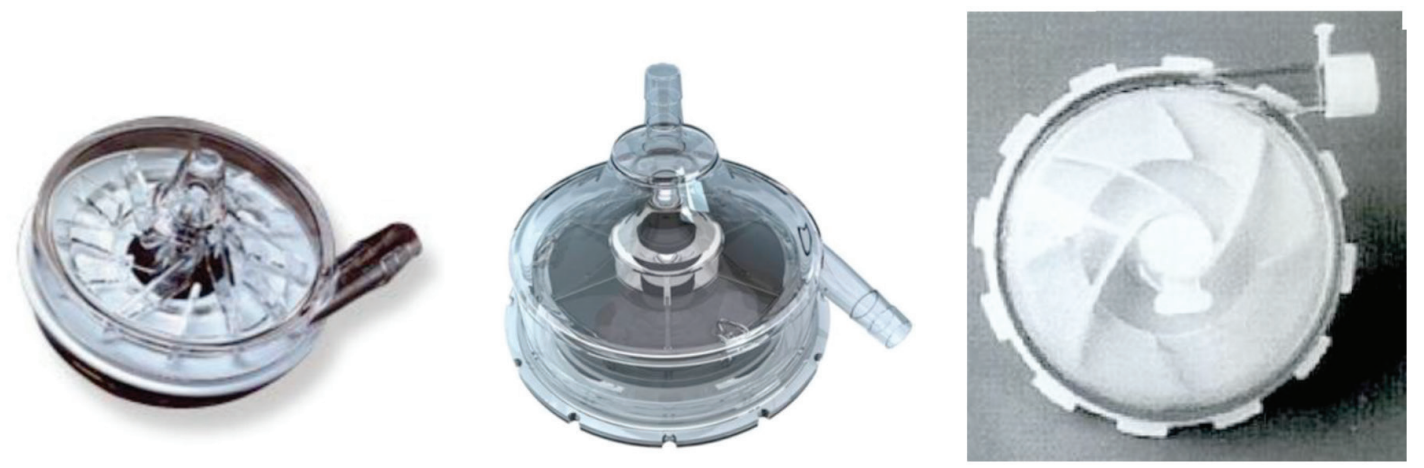

Figura 1. Imagens de dispositivos de assistência circulatória diversos, com aletas diferentes (não só a forma, mas também o número de pás difere), que serviram de inspiração para a bomba desenvolvida na pesquisa em questão. A primeira é a Sarns ${ }^{\mathrm{TM}}$ Disposable Centrifugal Pump, na sequência a bomba centrífuga CentriFlux, da Braile Biomédica e, por fim, a bomba centrífuga IsoFlow, da St. Jude Medical Inc. Fonte: laboratórios de pesquisa etnografados.

A proporção áurea é uma constante real algébrica extraída da Sequência de Fibonacci, conhecida também como proporção divina, obtida quando se divide uma reta em dois segmentos de forma que o segmento mais longo da reta dividida pelo segmento menor seja igual à reta completa dividida pelo segmento mais longo. 


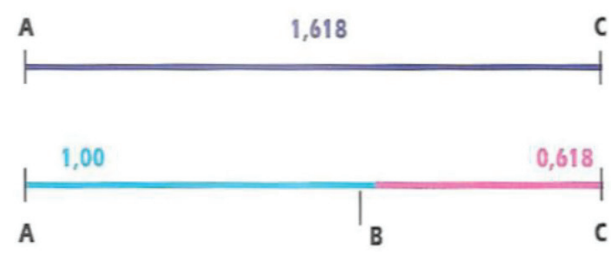

Figura 2. Segmento da reta dividida em média e extrema razão: $\boldsymbol{A B}=\mathbf{1}, \boldsymbol{B C}=\mathbf{0}, \mathbf{6 1 8}$ e $\boldsymbol{A C}=\mathbf{1}, \mathbf{6 1 8}$, resultando no segmento áureo. Fonte: tese de doutorado da interlocutora.

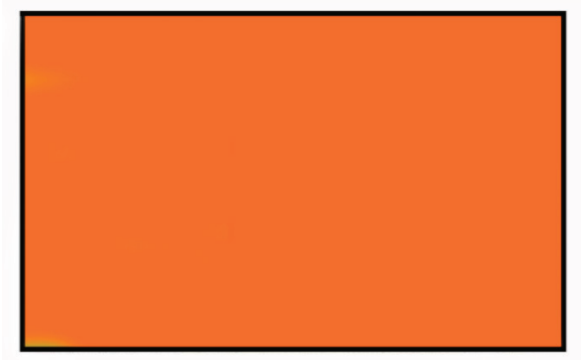

Figura 3. A partir do segmento áureo é possível construir o retângulo áureo, em que a razão de suas medidas obedece à proporção áurea, da qual é deduzida a espiral áurea.

Fonte: tese de doutorado da interlocutora.

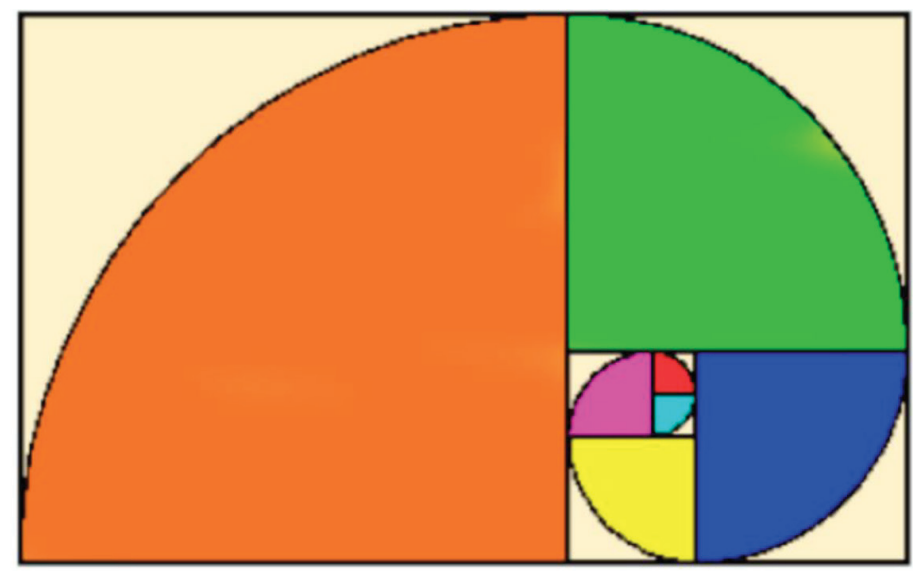

Figura 4. Espiral áurea construída a partir da sequência de Fibonacci, unindo quartos de círculos, um em cada novo quadrado. Fonte: tese de doutorado da interlocutora.

Embora não seja uma regra, a sequência de Fibonacci e a proporção áurea são frequentemente encontradas no mundo natural, como na forma de pétalas de flores, sementes, frutas, conchas e etc. Como a proporção áurea está associada a uma sequência que pode ser atribuída a uma reta, um retângulo ou uma espiral, há inúmeras formas de encontrá-la na geometria das coisas. Outro universo povoado pelas geometrias tidas como perfeitas é o da arte. 

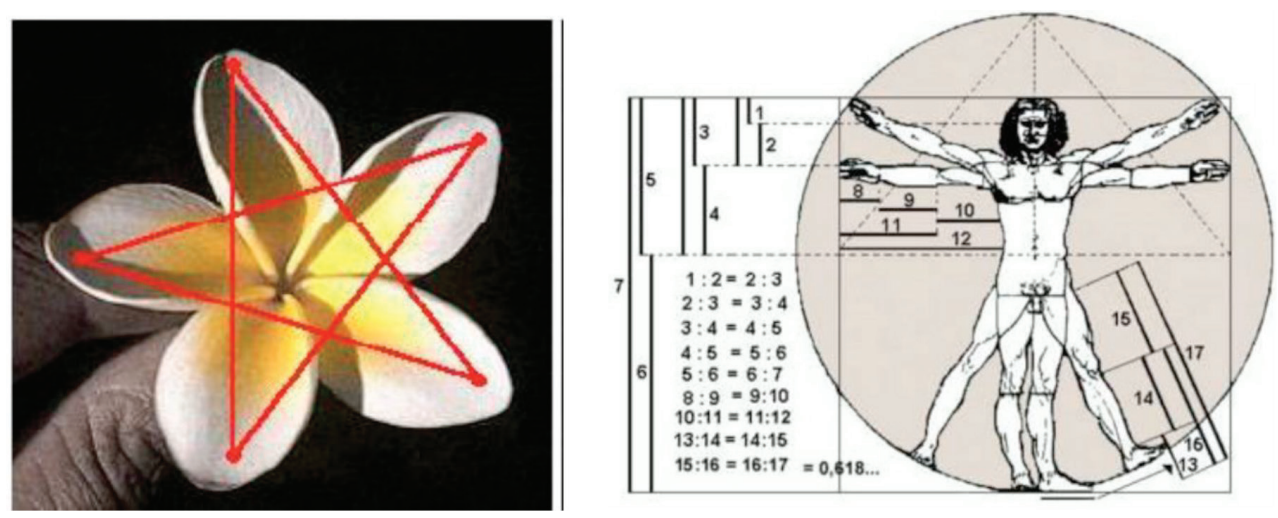

Figura 5. A flor de jasmim é um exemplo da proporção áurea presente no mundo, cuja proporção é representada pelo pentagrama, associado ao teorema de média (a partir do qual se encontra o valor de $\phi$ ). 0 Homem Vitruviano, de Leonardo da Vinci, é a típica representação de como a proporção áurea é encontrada na anatomia do corpo humano e de como foi investigada no mundo da arte.

Fonte: tese de doutorado da interlocutora.

É recorrente e antiga a investigação de geometrias presentes nas formas ditas naturais. Nelas busca-se inspiração para os desenhos dos artefatos desenvolvidos, sobretudo se for possível compreender/explicar sua "essência", ou melhor, matematizar sua linguagem. Recentemente, por exemplo, uma nova forma geométrica foi formulada por cientistas, chamada escutoide (scutoid). Tal geometria foi encontrada no corpo humano em estudos sobre o empacotamento de células epiteliais. Apesar de sua semelhança com prismas, a forma diferencia-se por possuir uma das arestas em forma de Y. 0 desenho faz referência ao formato tridimensional que células da pele tomam ao dobrar, caracterizado por superfícies curvas compostas de ao menos um dos vértices diferente das bases. A inspiração para a definição do termo da nova geometria vem do escutelo, ou seja, o casco dorsal do tórax de uma espécie de besouro denominado Protaetia speciosa. À aresta em Y está sendo atribuída a função de eficácia energética e de melhora da estabilidade. ${ }^{11}$
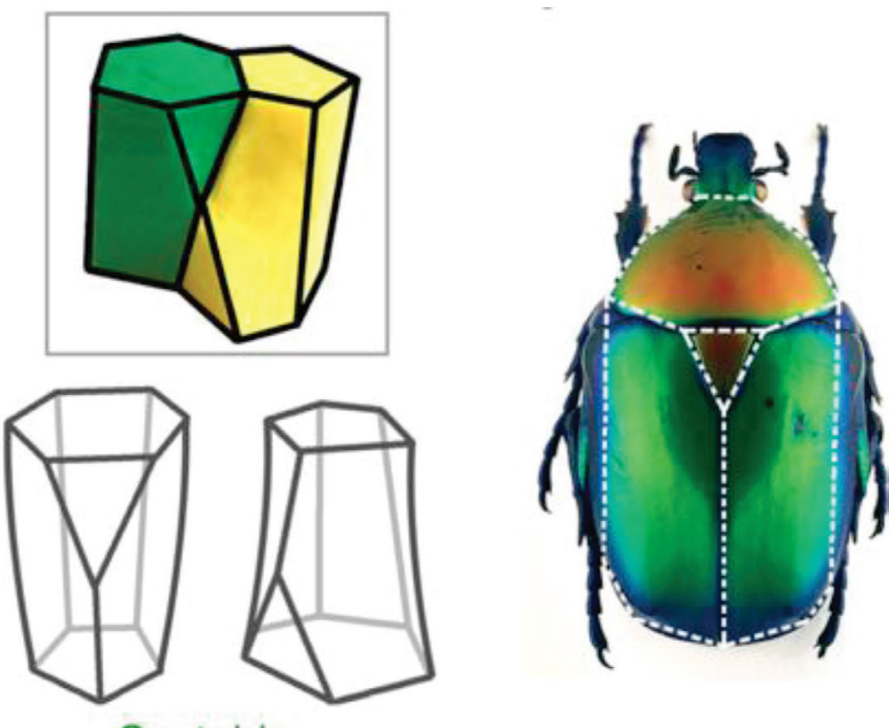

Scutoids

Figura 6. Nova forma geométrica encontrada em pesquisas a respeito do empacotamento de células epiteliais, cujo termo foi inspirado pela anatomia de um besouro.

Fonte: Nature. 
É curioso, e nada fortuito, que um tema de certa forma assessório como a relação entre a forma da aleta e uma proporção geométrica não só simétrica, mas "agradável", tenha sido sugerido a uma pesquisadora mulher. Digo isso porque os temas considerados secundários, suplementares, justamente por não serem vistos como fundamentais ao argumento mais propriamente "técnico" são normalmente reservados aos anexos ou apêndices. É o caso de uma das teses defendidas no mesmo período, em que o candidato se aventurou a refletir sobre as "funções semânticas" do coração, relacionada à atribuição de sentimentos e adjetivos. As elaborações encontram-se em um apêndice da tese, intitulado "cultura e tecnologia". Nele o engenheiro compila uma série de aparições na literatura, no cinema, nas artes plásticas, no senso comum, mas também na literatura acadêmica, como as contribuições de Harvey e Descartes, de conceitos e representações do coração. Seu argumento é que essa intersecção com a cultura é um fator relevante, no sentido de possibilitar uma disseminação, o que facilitaria a aceitação das tecnologias por parte dos pacientes. Embora tenha sido originalmente formulado como introdução à tese, na qualificação foi-lhe sugerido que transformasse em apêndice, por não ser um conteúdo fundamental ao argumento "técnico" desenvolvido no trabalho a respeito da produção de um controlador, ou seja, um sistema que ajusta a rotação dos dispositivos de fluxo contínuo (em relação à pulsatilidade nativa) de forma harmoniosa com 0 sistema fisiológico. $\frac{12}{2}$

É preciso destacar o fascínio entre os pesquisadores com quem me relacionei no campo da bioengenharia por temáticas entendidas como mais filosóficas, artísticas ou poéticas. Se nas teses e produções acadêmicas há pouco espaço ou espaços marginais para essas temáticas, para grande parte dos pesquisadores elas operam como agentes motivacionais e fator diferencial para a escolha da temática. Não é possível generalizar, mas há um sentimento compartilhado por muitos deles a respeito do caráter nobre associado à produção de órgãos artificiais. Aproximar-se à área da saúde os eleva à categoria de profissionais que atuam na produção de tecnologias que podem "salvar vidas". E mais, 0 coração é um órgão ilustre, como as diversas aparições artísticas listadas na tese supracitada evidenciam, a despeito dos esforços da biomedicina e da bioengenharia de apartar as dimensões simbólicas do funcionamento mecânico do órgão. Há uma concepção amplamente compartilhada de que trabalhar no desenvolvimento de corações artificiais é especial, o que faz deles também pesquisadores especiais. $\frac{13}{3}$

0 fascínio despertado nos engenheiros é também compartilhado por cardiologistas, cirurgiões e profissionais da saúde que atuam no transplante cardíaco ou implante de corações artificiais, como sugere a declaração de um dos cirurgiões entrevistados:

Bem, foi amor à primeira vista. Quando eu estava decidindo o que fazer, fui ver várias especialidades cirúrgicas e quando vi o coração batendo não teve jeito, entrei com tudo. (Aquiles, cirurgião cardíaco pediátrico)

Além de despertar amor à primeira vista, o coração foi descrito por um dos interlocutores da biomedicina em termos de sua beleza, associado à simplicidade e perfeição. Segundo o cardiologista, que tratava pacientes implantados e transplantados:

(...) O coração é uma bomba. Mas ele tem a capacidade de se tornar uma bomba com potência diferente, com performance diferente a cada segundo. Por exemplo, você está aqui conversando comigo, se você se emocionar, se você se chatear, ou se você tiver que sair correndo, ele vai se transformar numa bomba mais potente, exatamente para permitir que você receba fluxo de sangue para os músculos para sair correndo, receba mais sangue no cérebro para raciocinar. Então, apesar de ser uma bomba simples, de fisiologia simples, fácil de entender, ele se transforma em uma bomba com potência diferente para cada situação que você precisa. No sono ele é de um jeito, a hora que você acorda ele é de outro. E isso para você simular, para você desenvolver é muito difícil. Porque existe essa questão da perfeição mesmo, que a gente ainda não é capaz de desenvolver. Nada que desenvolveram se compara. (Narciso, cardiologista especializado em insuficiência cardíaca avançada)

Outro aspecto da beleza está relacionada à sua função vital. De acordo com Narciso, "não tem como você viver sem coração". Podemos considerar que ele se refere à função cardíaca, uma vez que se por um lado não é possível viver sem 
coração, por outro lado, atualmente é possível substituir sua função por meio de tecnologias de assistência circulatória, que possibilitam manter vivos corpos sem coração, ao menos temporariamente. Mas trata-se de um discurso que busca sustentar uma espécie de excepcionalismo do coração diante dos outros órgãos, como é possível constatar em sua explicação:

\begin{abstract}
Dá pra viver sem rim, dá pra viver sem 70\% do fígado. Mas o coração, para você ter uma ideia, quando você tem morte encefálica, você ainda tem vida. Você tem o paciente declarado morto, mas você ainda tem um corpo vivo e que é passível de beneficiar quase 20 pessoas. Isso só é mantido através do coração. Então quando o cérebro deixa de funcionar, o coração ainda mantém. Então assim, você só tem término da vida mesmo quando o coração morre. Então isso é uma coisa fantástica. (...) Ele não é tão complexo quanto um cérebro, por exemplo, ou quanto um fígado; em compensação o corpo vai deixando de existir à medida que o coração entra em insuficiência, inclusive o cérebro. Então, ele é que é o gerador de tudo. Ele que gera fluxo para que os outros órgãos possam funcionar. Ele é o órgão central do corpo. Nenhum órgão funciona sem o coração. Agora, você pode ter funcionamento sem rim, você pode ter funcionamento sem o estômago, você pode ter funcionamento sem intestinos, até 2 metros, por exemplo, agora o corpo não tem como funcionar sem o coração.
\end{abstract}

0 que tal formulação nos diz é que a vitalidade do coração é superior a órgãos como rim, estômago e intestinos, que podem estar reduzidos ou ter suas funções temporariamente suspensas. 0 mesmo não se aplica ao cérebro e ao pulmão, sequer citados, mas igualmente vitais. Estes, no entanto, parecem não despertar o mesmo fascínio e admiração, ao menos aos cardiologistas, que percebem no coração uma beleza singular.

0 coração, portanto, conjuga beleza, perfeição e desperta amor. Embora estes temas possam ser mais associados ao senso comum sobre o órgão, eles emergem no discurso oficioso também na prática médica. 0 discurso do órgão bomba, no entanto, impera nas práticas médico-científicas, bem como entre os pesquisadores da bioengenharia engajados em produzir dispositivos de assistência circulatória. Por isso a relação instituída entre as aletas da bomba a uma proporção divina, associada à perfeição e harmonia existente na natureza, parece destoar e nos coloca diante de duas possibilidades: ou a relação entre matemática e metafísica não é acessória nesse caso, e por isso não ficou relegada ao apêndice, ganhando centralidade na tese; ou o tema visto como "perfumaria", como acessório, menos técnico e de certa forma menos importante, é justamente destinado à pesquisadora mulher, cuja posição associada à feminilidade a coloca num papel também acessório num campo de pesquisa dominado por homens. De toda forma, parece se tratar de uma posição estratégica que permite deixar vazar os interesses metafísicos de pesquisadores comprometidos com um pragmatismo difícil de ser sustentado.

\title{
A matemática como linguagem da natureza
}

0 acesso matemático ao mundo é tradicionalmente compreendido nas cosmologias naturalistas ou modernas como uma forma cara de compreensão da sua linguagem. Como destaca o filósofo francês Michel Serres, "quando foi inventada a física, os filósofos diziam que a natureza se escondia sob o código de números e de letras da álgebra". 14

A ambição de compreender o mundo descobrindo seus números e as relações entre eles é antiga e não está reservada à cosmologia ocidental moderna, como evidencia o esforço aristotélico, bem como de outros pensadores gregos que 0 antecederam e 0 sucederam, dado que o conhecimento teórico grego é associado a um processo de matematização da natureza que molda as ciências da natureza. $\frac{15}{}$

Pitágoras considerava que todas as coisas eram números, ou poderiam ser representadas por números. Para Platão a matemática era, antes de mais nada, a chave da compreensão do universo; ela referia-se à ideia (suprema) de Bem. ${ }^{16}$ Em sua concepção deus geometriza o mundo eternamente. A academia platônica empenhou-se no desenvolvimento da geometria que, "embora inspirada nas técnicas egípcias de medir terrenos, é uma teoria das formas perfeitas das quais as coisas participam". ${ }^{17}$ A matemática era, portanto, a realidade última das coisas, o mundo ideal do qual os filósofos se ocupavam: 
(...) para Platão, o mundo das ideias, das coisas pensadas era o do real (bom, belo e verdadeiro). Nesse mundo existiam, de um lado, as ideias das formas geométricas, inteligidas pelo pensamento matemático (a dianóia); e do outro, as ideias das demais coisas, inclusive os ideais como: beleza, justiça e bondade, abarcáveis pelo pensamento dialético (noética). Em suma, a realidade última eram as ideias. Era sobre esse mundo ideal que a epistéme theoretike se ocupava. O restante, o mundo das coisas vistas e sentidas, só poderia ser objeto de conjecturas, crenças e opiniões. Essa é a origem das doutrinas metafísicas denominadas de idealismo. $\frac{18}{}$

Na filosofia platônica "o Demiurgo imprimiu uma forma estereométrica regular à matéria, ao transformá-la de caos em cosmos; fogo, ar, água e terra são constituídos de tetraedros, hexaedros, octaedros, icosaedros, respectivamente", 19 evidenciando um pressuposto metafísico de uma simetria universal. ${ }^{20}$

Mas seu discípulo, Aristóteles, não se contentou com o fundamento empírico matemático, substituindo-o por uma ciência dedutiva sistemática, passando da justificação pela experiência para razões teóricas. 11 Para Aristóteles, a quem a natureza é animada, dotada de movimento autônomo, "a realidade última está nas substâncias que individualizam os próprios entes". $\underline{22}$ Ou seja, ele abandona o idealismo platônico em nome de uma doutrina realista, segundo a qual 0 real está naquilo que as coisas são, e não nas ideias. $\underline{\underline{23}}$

Embora na física aristotélica a matemática esteja ausente, ele reconhece a importância central da matemática como linguagem própria da realidade: as partes essenciais da filosofia (divina e natural) são matemáticas. 0 ensino conjunto de matemática, lógica e filosofia da natureza nas universidades de Paris e Oxford nos séculos XIII e XIV é uma evidência da impregnação do pensamento aristotélico. Em Bologna e Pádua artes, direito e medicina acompanhavam o estudo da astrologia - para qual a geometria é essencial - dado o reconhecimento das influências dos astros sobre a fisiologia e psicologia humanas. $\underline{\underline{24}}$

A Aristóteles é atribuída a geometrização do raciocínio. Será, no entanto, o atomismo geometrizado de Platão 0 que será retomado por Galileu para defender a matematização da natureza como método para a elaboração de uma nova ciência. Assim:

A relação entre matemática e natureza (phýsis) tornou-se particularmente diferente, a partir do momento em que foram publicados, em 1638, os Discorsi e dimostrazioni matematiche intorno a due nuove scienze. Uma das razões principais foi o fato de Galileu romper com a tradição aristotélica que separava o trabalho do físico daquele do geômetra, pois enquanto o primeiro examinava coisas reais, o segundo examinava razões em função de abstrações - os métodos de cada um não podiam ser os mesmos, dentre outras coisas, porque o espaço vazio da geometria seria incompatível com a ideia de lugar natural e de cosmos. $\frac{25}{5}$

Apesar da recuperação do pensamento geométrico platônico por Galileu, os desenvolvimentos na ciência moderna foram marcados pelo contínuo esforço de afastamento da metafísica, como parte de uma estratégia de purificação, como veremos a seguir, se considerarmos o argumento da "abertura" do universo, formulado pelo historiador da ciência Alexandre Koyré.

\section{Matematização, desencantamento e desanimação do mundo nas ciências modernas}

As concepções matemáticas do universo manifestas na natureza, supostamente criadas por Deus, regidas por princípios de harmonia e perfeição são justamente aquelas que a revolução científica, ${ }^{26}$ como cunhou Alexandre Koyré, irá confrontar. $\underline{27}$ Em seu célebre livro Do Mundo Fechado ao Universo Infinito, 0 autor investiga um processo de revolução científica e filosófica do século XVII associado à destruição do Cosmos, ou seja, o desaparecimento dos conceitos 
válidos da concepção de mundo como um todo finito, fechado e ordenado hierarquicamente, o que implicou abandono de todas as considerações baseadas em conceitos de valor como perfeição, harmonia, significado, bem como a completa desvalorização do ser. Trata-se de um processo de destronamento do homem que decorreu numa mudança da imagem geocêntrica, eurocêntrica, antropocêntrica..$^{28}$

Ao recuperar a história do pensamento científico e filosófico dos séculos XVI e XVII Koyré evidencia o surgimento de uma nova cosmologia que substituiu o mundo geocêntrico pelo universo heliocêntrico. É por meio da ideia de infinito que esse autor procura mostrar como ocorre o estabelecimento de uma ampliação do universo - a ponto de torná-lo infinito - que corresponde ao processo de estabelecimento de uma ciência moderna, descrito como um processo gradual e cumulativo. Ele inicia sua narrativa resgatando o cardeal Nicolau de Cusa, teólogo e filósofo humanista, que, apesar de negar a finitude do mundo e sua contenção pelas paredes das esferas celestes, não chega a afirmar sua infinitude - seu universo não é infinito, mas é intérmino. ${ }^{29}$ Foi a concepção de Nicolau de Cusa que inaugurou o trabalho de desmantelamento que conduz à demolição do cosmo bem-ordenado, colocando sobre o mesmo plano ontológico a realidade da Terra e dos Céus. Ele transfere para o universo a caracterização de Deus como uma esfera cujo centro está em toda parte e cuja circunferência está em parte alguma, por isso Koyré considera que seu mundo, sua cosmologia, já não é mais o cosmo medieval, mas ainda não é o universo infinito dos modernos.

A próxima contribuição no sentido de ampliar as fronteiras do universo vem das elaborações de Marcelo Palingenius, a quem alguns analistas atribuem a afirmação da infinitude do universo. Porém, para Koyré, exceto pela afirmação enérgica da impossibilidade de se impor limite à ação criadora de Deus, não se encontra qualquer referência aos princípios da cosmologia de Nicolau de Cusa em sua obra. Koyré considera que é o céu de Deus que Palingenius afirma ser infinito, e não o mundo de Deus, mantendo a finitude do mundo material.

Já Copérnico, ao remover a Terra do centro do mundo e colocá-la entre os planetas, destrói os alicerces da ordem cósmica tradicional com sua estrutura hierárquica, formada por uma oposição entre domínio celeste e terrestre. Entretanto, embora seu mundo não seja mais estruturado hierarquicamente, ainda é um mundo ordenado e finito. Para Koyré, o efeito da revolução provocada por Copérnico foi espalhar o ceticismo e perplexidade. Apesar de finito, Copérnico dá o que Koyré considera como o primeiro passo para abri-lo, ao deter o movimento da esfera das estrelas fixas, atribuindo movimento à Terra, tornando o mundo incomensurável. Ainda que não considere o universo infinito, Copérnico considerava o mundo das estrelas fixas infinito. Além disso, ele removeu uma das mais válidas objeções científicas contra a infinitude do universo a respeito das esferas celestes, que tratava-se de um fato empírico e sensorial. Em seu raciocínio a realidade ou uma ligação física substitui uma realidade ou ligação metafísica, uma estrutura cósmica é substituída por uma força física. Apesar de ampliar o mundo, no entanto, Koyré pondera: "Não nos aproximamos do universo infinito aumentando as dimensões de nosso mundo. Podemos torná-lo tão grande quanto quisermos; isto não nos situa em nada mais perto da infinitude". .0

A argumentação gradativa de Koyré, que recorre à contribuição progressiva de certos personagens da história da ciência, evidencia que houve um processo de adições sucessivas que rompeu com a visão de cosmos medieval. Nesse sentido, o inglês Thomas Digges é considerado por Koyré como o primeiro copernicano a substituir a concepção de seu mestre de um mundo fechado por um mundo aberto, o que é normalmente atribuído a Giordano Bruno. Apesar de ainda encontrar-se dominado pela concepção ou imagem religiosa copernicana de um céu situado no espaço, Digges apresentava dúvidas e hesitações a respeito da visão de mundo copernicana. 0 passo definitivo de Digges, para Koyré, seria o de afirmar que a esfera celeste das estrelas fixas, defendido por Copérnico, não existia, indicando a existência de um céu estrelado que se estendia infinitamente.

Giordano Bruno - a quem normalmente é atribuída a doutrina do universo descentralizado, infinito e infinitamente povoado - é visto por Koyré como aquele que afirma a infinitude do mundo. Ele anuncia a extinção das esferas que nos separavam dos vastos espaços abertos e do universo eterno, infinito, sempre em mutação. Entretanto, ele aponta para o fato de que o infinito não pode ser objeto dos sentidos e percepção sensorial, dado que é inacessível e irrepresentável. Para ele a verdade reside na razão, por meio de processos de argumentação e discussão. Desse modo, ele reconhece 
a diferença entre a infinitude intensiva e perfeitamente simples de Deus e a infinitude extensiva e múltipla do mundo, ou seja, comparado com Deus o mundo não passa de um ponto, um nada. Nesse sentido, destronar a Terra do centro do universo, embora não tenha sido visto como uma degradação para Nicolau de Cusa, por exemplo, que afirma sua promoção aos planos dos astros nobres, o é para Giordano Bruno, que desqualifica a Terra em sua posição no universo e em comparação a Deus. Entretanto, somente depois das grandes descobertas telescópicas de Galileu sua doutrina foi aceita e se tornou uma concepção de mundo legítima.

Koyré retoma as elaborações de Kepler para contrapor o que considera uma nova concepção astronômica a uma nova metafísica, mostrando que Kepler contrapõe-se a Bruno, não em relação à ação criadora de Deus, mas a uma concepção de ciência astronômica baseada nos fenômenos e limitada por eles. É com a ideia de que a concepção de infinitude do universo está associada a uma doutrina puramente metafísica que Koyré argumenta sobre o distanciamento entre ciência e metafísica, reservando à última a concepção de infinitude.

Por não estar baseada em empiria, Kepler confere à infinitude do universo uma dimensão metafísica. Sua recusa à doutrina metafísica baseava-se em suas convicções religiosas, uma vez que via no mundo uma expressão de Deus, materializado em uma estrutura e ordem harmônica e matemática. Para ele a infinitude do universo remontava aos antigos filósofos pagãos, o que era incompatível com sua devoção cristã. A concepção de infinito não era uma questão de caráter dogmático, por isso deveria ser tratada por meio de raciocínio científico. Tratava-se de uma questão que poderia ser apropriada pelo empirismo, embora não pudesse basear-se em empirismo. E é nesse sentido que Kepler se afasta de Giordano Bruno, ainda que ambos aproximassem a ideia do universo à criação divina - Bruno afirmando a infinitude do universo, enquanto Kepler a negava. Para Koyré, embora o posicionamento de Kepler possa ser visto como ilógico, ele é perfeitamente coerente com sua argumentação, ao postular o caráter empírico da ciência que deveria, portanto, lidar com dados observáveis, enquanto Giordano Bruno afirmava a infinitude do universo, considerando que o infinito não poderia ser objeto dos sentidos por ser inacessível e irrepresentável, tratando-se de um conceito para 0 intelecto, apartado da experiência sensorial. Nesse sentido, Koyré ressalta que no que diz respeito ao raciocínio de Kepler, ao considerar a distribuição das estrelas no espaço, este não trata da distribuição abstrata no espaço físico, mas sim de uma distribuição concreta das estrelas que corresponde à aparência do céu.

Apoiando-se em argumentos de Kepler, Koyré considera que ainda que pudéssemos supor que a região das estrelas fixas seja ilimitada, esta seria uma suposição puramente gratuita, que não se baseia na experiência. Kepler considerava que uma estrela visível não poderia estar a uma distância infinita, ou seja, onde quer que se colocasse as estrelas, elas estariam sempre a uma distância finita. São essas estrelas e esse espaço finito que interessavam a Kepler, uma vez que o infinito é aquilo que está além de todo o número e toda a medida. No limite, Kepler parece dizer que não é o universo que é finito, mas sim o mundo óptico. Sua contribuição está sobretudo no empirismo proposto, que propiciará o estabelecimento de uma ciência moderna. Sua manobra, no entanto, afasta a metafísica, ao considerar que um espaço vazio não pode ter existência real.

Seguindo a argumentação da ampliação do universo até sua abertura ao infinito - e o deslocamento da compreensão do infinito como pertencente a um domínio não científico - institui-se uma narrativa de purificação na história da ciência. Em sua narrativa Koyré descreve um processo de separação de disciplinas, demonstrando que a ciência gradualmente torna-se empírica e objetiva, apartada da metafísica.

Ao abordar as obras de Galileu e Descartes a narrativa se completa, ${ }^{31}$ à medida que Koyré apresenta esse momento da astronomia como uma fase instrumental da ciência, marcada pela invenção do telescópio e os desdobramentos por ele permitidos, que pareciam indicar a possibilidade de superação das limitações impostas pela natureza. Nesse cenário, a finitude ou infinitude não são consideradas mais questões importantes, pois tratava-se de um problema insolúvel. Entretanto, Galileu não admitia a limitação do mundo, muito menos acreditava que este fosse fechado por uma esfera de estrelas fixas.

Inaugurada por Galileu, que apresentava ideias baseadas na descoberta de novos astros no espaço físico abandonando suposições metafísicas ao prender-se à materialização do espaço - uma nova e moderna ciência surge, 
consolidada por Newton, visto por Koyré como um cientista profissional, dado que se interessava mais pela investigação matemática da natureza, do que por filosofia e desenvolvimentos metafísicos.

A despeito do esforço progressivo na história das ciências modernas de extirpar a metafísica do seu escopo, no entanto, o filósofo da ciência Edwin Arthur Burtt, em As Bases Metafísicas da Ciência Moderna, empenha-se em produzir um estudo histórico e crítico sobre o prevalecimento de certas premissas que caracterizam o pensamento moderno. $\frac{32}{.}$ Interessam-lhe, sobretudo, as bases metafísicas do trabalho de Newton para o avanço matemático da mente, ainda que este tenha tentado evitar a metafísica, desprezando hipóteses não deduzidas imediatamente de fenômenos.

Ainda que tome a distinção entre ciência e metafísica como um dado que se estabeleceu com a ciência moderna, Burtt defende que Newton constituía-se mais como filósofo do que como cientista (de acordo com a distinção que fazemos atualmente desses termos), e argumenta que Newton não possuía rivais cientistas, ao passo que não escapava a críticas como metafísico $\frac{33}{\underline{3}}$ Para Burtt, ele não apenas encontrou um uso matemático para conceitos como força e massa como deu novos significados a velhos termos como espaço e tempo, que se tornaram categorias fundamentais do pensamento humano. Burtt considera haver metafísica nos desenvolvimentos de Newton, tanto em seu conceito geral do mundo físico e de sua relação com o homem, como em suas concepções sobre espaço e tempo, assim como suas ideias sobre a natureza e função do éter e sobre a existência de Deus e sua relação com o mundo, desvendada pela ciência.$\underline{34}$ Desse modo, 0 âmago da nova metafísica científica diz respeito à atribuição de realidade fundamental e eficácia casual ao mundo da matemática. A metafísica medieval é seguida por uma concepção mecânico-matemática do universo, uma vez que os fundadores da filosofia da ciência estavam mergulhados no estudo matemático da natureza. Ainda que tentassem evitá-la, a metafísica tornava-se um instrumento para a conquista matemática do mundo. Nesse sentido, Burtt considera que a base experimental separou a filosofia da ciência, porém, a despeito dos esforços de afastar-se da metafísica, todos os cientistas apresentavam preocupações com as causas primeiras e teleológicas.

Ecoando a narrativa de Burtt e seu questionamento sobre o sucesso das ciências em apartar a metafísica do seu escopo, trago aqui o caso etnográfico apresentado anteriormente a respeito do desenvolvimento de um dispositivo de assistência circulatória que permite considerar a emergência de aspectos metafísicos na produção de conhecimento e práticas na bioengenharia. 0 intuito de resgatar a história do pensamento e da instituição de uma ciência supostamente apartada da metafísica era desnaturalizar essa divisão, que longe de dada, foi paulatinamente instituída - embora possamos mesmo questionar sua efetivação. Há nenhuma ou pouquíssima correlação entre astronomia e sua instituição como ciência exemplar na história do pensamento moderno e a produção de corações artificiais na contemporaneidade. 0 intuito ao resgatar o longo processo de elaboração da infinitude do universo, no entanto, diz respeito à tentativa de evidenciar o intenso empenho de afastamento da metafísica, tão significativo no argumento de Koyré para a formulação de uma ciência moderna. Se, apesar dos esforços, a metafísica jamais pôde ser plenamente apartada, como sugere Burtt, é preciso ao menos reconhecer seu abandono no discurso oficial como alvo de interesse nas ciências modernas.

Falar em perfeição, harmonia e beleza pode ser considerada uma restituição da metafisica? A aproximação da forma da aleta do dispositivo de assistência circulatória à proporção áurea, ou melhor, a justificativa matemática associada a um critério estético, pode ser tomada como o acolhimento de temáticas metafísicas no âmbito da produção científica? Além da justificativa geométrica da associação à proporção áurea, a eficácia do desenho da aleta é argumentada empiricamente, ou seja, sua adequação é comprovada por ensaios e experimentos in vitro que demonstraram que sua forma era adequada, pois além de apropriada para a função destinada - ou seja, para a circulação do sangue - 0 design do artefato não produzia danos às células sanguíneas (ou produzia danos dentro de limites aceitáveis em comparação a outros dispositivos similares). A ocorrência de hemólise é um dos principais desafios associados à produção de assistência circulatória, dado que os dispositivos mecânicos podem atuar como "liquidificadores de células", como certa vez colocou um dos interlocutores da bioengenharia. Mas a justificativa da forma das aletas do dispositivo a uma medida relacionada à simetria e perfeição, frequentemente encontrada nas plantas, no mundo e em obras de arte evidencia o esforço de associação e dedução abstratas, possibilitando a emergência de concepções, moralidades e pensamento metafísico no âmbito da bioengenharia. 


\title{
Platônicos, aristotélicos ou sexistas?
}

\begin{abstract}
Elas não têm mãos para manejar o mundo, e, no entanto, seria difícil encontrar agentes mais hábeis na construção de formas. As plantas não são apenas os artesãos mais finos de nosso cosmos, são também as espécies que abriram para a vida o mundo das formas, a forma de vida que fez do mundo o lugar da figurabilidade infinita. (...)

A ausência de mãos não assinala uma falta, mas antes a consequência de uma imersão sem resto na própria matéria, que elas modelam incessantemente. As plantas coincidem com as formas que inventam: todas as formas são para elas declinações do ser e não apenas do fazer e do agir. Criar uma forma significa atravessá-la com todo seu ser, como se atravessam idades ou etapas da própria existência. $\frac{35}{5}$
\end{abstract}

Há muitas maneiras de projetar um motor e acoplar nele aletas capazes de empurrar o sangue, de modo a exercer a principal função dos ventrículos no coração nativo, de acordo com as concepções biomédicas sobre a fisiologia humana - tarefa mecânica que exige energia e potência para garantir a perfusão das células. $\cdot \frac{36}{}$ Algumas dessas soluções mecânicas se provam mais eficazes do que outras. Argumentar a favor de um determinado desenho ou projeto é uma tarefa que exige evidências empíricas, mas também argumentação retórica. Aproximar determinada geometria a formas tidas como harmônicas, simétricas, perfeitas e belas pode fortalecer a "robustez" de um artefato e do seu conceito.

É preciso reforçar, no entanto, que a emergência de discursos metafísicos associados às evidências empíricas para justificar a adequação geométrica de um dispositivo caracteriza-se como um desvio entre os interlocutores da bioengenharia, e não uma recorrência. É inevitável considerar que esta coincide com outra eventualidade, que é a presença de mulheres desenvolvendo pesquisas de doutorado na área. Embora não fosse a primeira, a candidata em questão somava-se a uma minoria de mulheres presentes no campo naquele momento.

Considerar que a sugestão de apostar em uma argumentação metafísica está relacionada a uma questão de gênero, no entanto, não implica tomá-la como uma habilidade feminina, ou seja, não se trata da suposição de que mulheres seriam mais inclinadas às reflexões metafísicas, e muito menos que seriam inapropriadas ao desenvolvimento técnico "forte", ou seja, às áreas vistas como mais duras ou legítimas na engenharia. Não pretendo com essa diferenciação produzir uma hierarquia entre áreas. Muito menos afirmar que essa distinção é de fato operante. Não se pode desconsiderar, no entanto, que hierarquizações entre temáticas e áreas podem estrategicamente ser instituídas, e quase sempre são sustentadas por naturalizações de gênero, não à toa as áreas mais tradicionais das ciências e das engenharias são conhecidas como mais duras, fortes, características atribuídas à masculinidade, em oposição à leveza ou fraqueza - que são tomadas como femininas.

Uma análise ilustrativa da problemática aqui abordada pode ser encontrada no argumento de Vinciane Despret em seu artigo "Culture and Gender do not Dissolve into how Scientists 'read' Nature: Thelma Rowell's Heterodoxy".$\underline{37}$ Nesse trabalho, a filósofa da ciência recupera o caso da primatologia para pensar as relações de gênero num campo específico de produção científica. Ela descreve a tomada da disciplina por uma geração de mulheres que quebraram paradigmas e transformaram o modo como os babuínos eram pensados. No início dos anos 1960 as observações de Thelma Rowell sobre os babuínos machos da floresta de Ishasha, em Uganda, permitiu que ela questionasse o modo como eles eram caracterizados como agressivos. Em sua análise, existiam tensões entre machos, mas estas eram principalmente expressas pela ausência de aliciamento entre eles e uma alta troca de gestos de "polidez" ou "conciliação". A impressão dominante da interação entre os machos era de cooperação ativa. Até as suas observações, no entanto, os babuínos haviam sido descritos unanimemente como extremamente competitivos e agressivos uns com os outros.

A imagem de animais agressivos e muito competitivos se originou no final da década de 1920, com as observações do zoólogo Solly Zuckerman numa colônia de babuínos num zoológico de Londres. Análises posteriores evidenciaram como a história dessa colônia influenciou consideravelmente a construção da imagem e das teorias que explicavam a organização social dos primatas: dos cem babuínos, a maioria machos, vinte e sete adultos morreram durante os 
primeiros seis meses, a maioria deles mostrando feridas indicando participação em lutas. Ou seja, tratava-se de uma colônia composta por muitos animais estranhos uns aos outros, confinados em um espaço pequeno, e combinados em proporção sexual inadequada. 0 que para Zuckerman parecia ser um comportamento "normal", a partir do qual ele extrapolou uma tese geral a respeito da organização social dos primatas, era na verdade um laboratório absolutamente artificial e problemático. Evidências posteriores demonstraram que a hierarquia rígida nada mais era do que a resposta dos animais à desordem social criada pela situação, ou seja, o estresse ao qual eram expostos induzia a competição.

Sua tese sobre os instintos sexuais como o fator de integração do grupo, a competição sexual como base da sociedade primata, sua teoria da dominação continuou a crescer, assim como a convicção sobre a insignificância social das fêmeas para a organização social.

Na análise de Rowell, no entanto, não apenas os babuínos viviam em paz e harmonia, com pouca ou nenhuma interação competitiva, mas também não parecia haver hierarquia observável. Enquanto nos estudos anteriores os machos eram líderes, no grupo de Rowell eram as fêmeas mais velhas que determinavam a rota diária - contrariedade que foi chamada por alguns pesquisadores como "efeito Thelma".

Para Despret, essa controvérsia poderia ser encerrada apoiando-se numa solução proposta por especialistas dos estudos sociais da ciência e da tecnologia para quem os animais são guiados pelas expectativas de quem os estuda. Nesse caso, adotar essa abordagem significa que a contrariedade da Thelma Rowell pode ser colocada como uma questão de gênero, no sentido de que mulheres teriam determinadas habilidades e características que levariam a resultados de pesquisa peculiares. $\frac{38}{}$ Outra linha de argumentação, proposta pela filósofa Donna Haraway, considera que 0 tema unificador na primatologia feita por mulheres refere-se à alta probabilidade de serem céticas em relação a generalizações, apostando em explicações cheias de diversidade, complexidade e contextualidade.

A essa camada Despret acrescenta outras, ao abordar o papel social das pesquisadoras na academia naquele período, evidenciando a impossibilidade de acesso a posições acadêmicas, relegando às mulheres a pesquisa de campo, o que implica revisão da hipótese de que as mulheres eram melhores observadoras porque eram mais pacientes ou mais emocionalmente conectadas aos sujeitos da pesquisa, ou seja, os animais. Ela sugere, portanto, que é preciso considerar que as mulheres eram melhores observadoras porque ficavam mais tempo no campo, com os animais, como a experiência da pesquisadora Rowell evidencia - ela passou 5 anos com os babuínos, em Uganda, onde esteve para acompanhar o marido, que ocupava um posto numa universidade. Os longos trabalhos de campos levavam a observações inesperadas. Como demonstra Despret, a hipótese de que as fêmeas eram o cerne da organização social é fruto da observação de que nenhum macho adulto permanecia durante todo o tempo do estudo. Eles mudavam constantemente de um grupo para outro, e o caráter nômade dos machos ainda não havia sido observado, porque os pesquisadores não haviam permanecido tempo suficiente no campo - ou não estavam suficientemente familiarizados com os animais a ponto de reconhecer os indivíduos e diferenciá-los.

É curioso que parece haver expectativas e interpretações semelhantes em relação ao papel das mulheres no campo de produção de dispositivos de assistência circulatória. Nesse sentido, pensando a partir da situação trazida aqui, a habilidade de justificar a definição das aletas e sua relação com um padrão numérico e geométrico em nada remete a uma qualidade feminina, que em si deve ser questionada. Mas a associação comum entre beleza e perfeição aos atributos femininos pode ter relegado à pesquisadora o papel de resgaste da metafísica num campo altamente purificado, movido supostamente por razões puramente pragmáticas, no qual o tecnicismo limitado (e limitante) impera. À pesquisadora restou desenvolver a relação sugerida pela banca, composta apenas por homens, assim como as mulheres na primatologia estavam destinadas ao trabalho de campo, já que estavam impossibilitadas de assumir postos acadêmicos.

É evidente que a ausência de mulheres em determinadas áreas não pode ser justificada por capacidades vistas como inatas, mas pelo histórico de exclusão e desestímulo persistente. Cabe lembrar que a divisão social do trabalho constituiu-se historicamente nos mais diversos campos sem nenhuma relação com habilidades naturais, mas sim socialmente naturalizadas. Nesse sentido, não se trata de definir e muito menos naturalizar habilidades em termos de 
divisão de gênero, mas sim destacar a existência de expectativas ou papeis sociais atribuídos a cada um na produção do conhecimento e desenvolvimento de tecnologias. Não há nada que faz das mulheres mais aptas ou destinadas à metafísica, inclusive porque esta não se sustenta sozinha. Ou seja, para argumentar a favor de uma geometria que é atravessada por dimensões metafísicas relativas à harmonia das formas, sua beleza e perfeição associada a conceitos ideais, em concordância com uma matematização da natureza, é preciso dominar e manipular os números, 0 conhecimento matemático e formal tanto quanto se a justificativa estivesse purificada, apartada da metafísica. Não à toa, grande parte do esforço da tese supracitada debruçou-se na tarefa de articulação da proporção áurea às medidas e proporções das aletas, o que demandou uma verdadeira ginástica dos números, uma manipulação complexa da matemática e da geometria. 0 esforço é justificado, no entanto, pelo potencial de alcançar melhores resultados, uma vez que partir de uma geometria conceitualmente justificada e verificada é melhor do que partir de uma geometria arbitrária, como sugere a metodologia "passo a passo" $\underline{\underline{39}}$ aplicada em outras investigações no mesmo campo, como sugere 0 argumento da pesquisadora.

Assim, a justificativa metafísica opera no sentido de fortalecer a adequação técnica e moral da forma das aletas projetadas. Cabe destacar que, ao considerar que uma forma geométrica é inspirada na/pelo mundo natural, supomos não só o modo como a suposta natureza é codificada e compreendida, mas também consideramos os efeitos da geometrização das formas. No caso da ciência moderna, o esforço insistente em matematizar a linguagem do universo incorre não só na racionalização, mas no empenho oficial de apartar a metafísica, que parece, no entanto, ecoar oficiosamente.

A presente especulação está longe de abordar profundamente a complexa relação entre ciência, matemática e a concepção geométrica do mundo e dos fenômenos. 0 esforço, no entanto, foi evidenciar a existência de discursos metafísicos imiscuídos nas elaborações matemáticas e geométricas, bem como nas próprias concepções de natureza, do órgão nativo, da fisiologia humana.

É preciso reconhecer a conveniência de se compreender e codificar o mundo a partir de uma linguagem matemática, sobretudo por seu poder preditivo, oportuno à ciência e produção de tecnologia. No entanto, enfrentamos na contemporaneidade o desafio de buscar outras formas de comunicação, novas formas de compreensão das linguagens faladas pelas coisas do mundo, para que possamos estabelecer novos contratos. ${ }^{40}$ Conforme afirma Michel Serres, desconhecemos a língua do mundo, ou conhecemos apenas as diversas versões animista, religiosa ou matemática. Faz-se necessário, no entanto, buscar novas formas de compreensão, novos contratos, e acrescentar ao contrato social um contrato natural de simbiose e de reciprocidade em que a nossa relação com as coisas permita a contemplação e o respeito, em que o conhecimento não suponha a propriedade, nem a ação o domínio.

0 empenho insistente da ciência moderna em abordar o mundo a partir da matemática, nos levou a contratos limitados. Retornando a Serres uma última vez, a Terra nos fala a partir da linguagem de forças, de ligações e interações, o que é suficiente para celebrar um contrato. É preciso buscar nas trocas físico-químicas, elétricas, mas também hidráulicas e mecânicas, novas compreensões para além da matemática.

\section{Notas e referências bibliográficas}

Marisol Marini é doutora em Antropologia Social pela Universidade de São Paulo. E-mail: marisolmmarini@gmail.com

1 Uma primeira versão desse trabalho foi apresentada no workshop interno do Laboratório de Estudos Pós-Disciplinares (LAPOD) do Instituto de Estudos Brasileiros da Universidade de São Paulo, em 2018. Agradeço à professora Joana Cabral de Oliveira pelos preciosos comentários e sugestões, bem como às e aos colegas que participaram do encontro.

2 Utilizo coração artificial como um termo guarda-chuva para me referir a distintas tecnologias e usos de assistência circulatória cardíaca. A bomba em desenvolvimento na tese que será aqui investigada era um dispositivo de uso temporário. Trata-se de uma aplicação denominada Circulação Extracorpórea (CEC), que visa oferecer suporte circulatório mecânico durante atos cirúrgicos, ou por um curto período, antes ou depois de procedimentos. A bomba é acoplada à máquina de circulação extracorpórea, um aparato tecnológico grande, responsável pela substituição da função do coração enquanto este está "desligado" ou insuficiente. Como ponte para recuperação a bomba é utilizada para auxiliar a função cardíaca, oferecendo suporte circulatório até 
que o paciente se recupere. Como ponte para transplante o paciente é auxiliado, mantido vivo com a ajuda do dispositivo enquanto aguarda por um órgão compatível para ser transplantado. É possível também que essas bombas sejam empregadas como ponte para decisão, que é a utilização de um dispositivo descartável em um paciente que deverá receber um transplante ou implante de um dispositivo para assistência prolongada. Cada uso tem as suas especificidades e demanda bombas distintas, caracterizadas pela sua maior resistência, melhor hemodinâmica, melhor biocompatibilidade e etc.

3 É preciso destacar que a pesquisa em questão é um trabalho de engenharia em interlocução com a biomedicina. Não há interesse declarado e explícito na tese em desenvolver temáticas metafísicas ou filosóficas. Trata-se de um típico trabalho no campo da produção de tecnologias cardíacas interessado no aprimoramento de dispositivos, o que no caso dessa pesquisa implicou realização e desenvolvimento de testes in vitro, utilização de cálculos matemáticos para o desenho das aletas, testes de bancada com o dispositivo desenvolvido. A pesquisa resultou não só em um artefato, como produziu diálogos com os desenvolvimentos técnicos e conceituais do campo da bioengenharia. 0 reconhecimento da presença de reflexões metafísicas é uma leitura minha. Agradeço ao colega da bioengenharia Bruno Jesus dos Santos, que em sua leitura do artigo me alertou para o risco de parecer que a tese analisada era um trabalho de investigação metafísica.

4 Ver SCHIEBINGER, Londa. O feminismo mudou a ciência? Bauru, SP: EDUSC, 2001; LETA, Jacqueline. As mulheres na ciência brasileira: crescimento, contrastes e um perfil de sucesso. Estudos Avançados, v. 17, n. 49, p. 271-284, 2003; COSTA, Maria Conceição da. Ainda somos poucas: exclusão e invisibilidade na ciência. Cadernos Pagu, n. 27, p. 455-459, 2006.

5 MARINI, Marisol. Corpos Biônicos e Órgãos Intercambiáveis: A produção de saberes e práticas sobre corações não-humanos. 2018. 251 f. Tese (Doutorado em Antropologia Social) - Faculdade de Filosofia, Letras e Ciências Humanas da Universidade de São Paulo, USP, São Paulo. Tese orientada por Heloísa Buarque de Almeida e Stelio Alessandro Marras, financiada pela FAPESP (Processo n 2013/02389-2).

6 SHARP, Lesley A. The Transplant Imaginary: Mechanical Hearts, Animal Parts, and Moral Thinking in Highly Experimental Science. Berkeley: University of California Press, 2014.

7 SHARP, Lesley A. The invisible Woman: The Bioesthetics of Engineered Bodies. Body \& Society, vol. 17, p. 1-30, 2011.

8 SHARP, op. cit., 2014, p. 119-120.

9 É complexo apresentar esses números sem comprometer o sigilo das instituições e dos interlocutores. Além disso, o modo como tratei as redes na pesquisa de doutorado denota seu caráter fluido e que não pode ser limitado às fronteiras das instituições, considerando que as redes foram pensadas a partir das trocas e relações de pesquisa estabelecidas pelos atores, não se limitando, portanto, às instituições. Acredito, no entanto, que numericamente esses dados não são relevantes, uma vez que não são representativos estatisticamente. Se nos limitarmos às duas instituições especificamente de bioengenharia, por exemplo, e recortarmos a amostra apenas entre aqueles que trabalham com corações artificiais, a proporção de professores homens é de 5 para nenhuma mulher. Entre as pesquisadoras de mestrado e doutorado cabe destacar também que uma parte delas se ocupa do eixo dos biomateriais, ou dos dispositivos infantis, imaginados talvez como mais "leves" ou "delicados", como na lógica apresentada pela interlocutora da Sharp. Caberia uma investigação cuidadosa, no entanto, para buscar compreender se de fato e quais seriam as razões para um maior acolhimento das mulheres na subárea de biomateriais. Na cardiologia o número de mulheres é mais representativo.

10 Em relação à compreensão da feminilidade, destaco que muitas vezes o que era descrito como feminino parecia se referir a um modo de pensar distinto num campo habitado por pouca ou nenhuma diversidade. A engenharia é dominada por homens brancos, de classe média, o que até hoje, mesmo com a implantação das cotas em universidades não mudou muito, como demonstram dados do Instituto Nacional de Pesquisas Educacionais a respeito da proporção de brancos, afrodescendentes e indígenas em comparação à ampliação da participação e diversidade nas Humanidades.

11 A descoberta foi publicada na revista Nature (https://www.nature.com/articles/s41467-018-05376-1, acessado em dezembro de 2018) e virou notícia em canais de divulgação científica (https://revistagalileu.globo.com/Ciencia/noticia/2018/08/pesquisadores-descobrem-nova-forma-geometrica.html, acessado em dezembro de 2018).

12 É possível argumentar que a questão da geometria relaciona-se e impacta diretamente o desenvolvimento das tecnologias, enquanto que o "pano de fundo cultural" não. Meu ponto, no entanto, é que o senso comum, as representações sobre o órgão, sejam elas vistas como científicas ou não - como por exemplo a compreensão do corpo e do coração como uma máquina, decorrente das elaborações de Harvey e Descartes - atravessam a produção desses dispositivos tanto quanto a geometria, a matemática etc.

13 Na tese argumento a respeito da ocorrência de uma coprodução entre pesquisadores e dispositivos, demonstrando que o sucesso dos corações artificiais é compartilhado entre diversos actantes humanos e não-humanos.

14 SERRES, Michel. 0 contrato natural. Lisboa: Instituto Piaget, 1990, p. 67.

15 VARGAS, Milton. História da matematização da natureza. Estudos Avançados, vol. 10, p. 249-276, 1996.

16 CORNELLI, Gabriele e COELHO, Maria Cecília de Miranda N. “Quem não é geômetra que não entre!” Geometria, filosofia e platonismo. Kriterion (Belo Horizonte), n. 116, p. 417-435, 2007.

17 IDEM, p. 251.

18 IDEM, p. 251.

19 CORNELLI e COELHO, op. cit., 2007, p. 420.

20 Segundo Milton Vargas, “Platão tratou da natureza e da sua origem em um de seus últimos diálogos: o Timeo, cujo subtítulo é exatamente Peri Physei (a respeito da natureza). Nesse diálogo ele assume a posição pitagórica quando descreve a construção da physis pelo Demiurgo - cujos olhos estão fixos num modelo pré-estabelecido - misturando, em proporções harmoniosas, duas substâncias indefinidas, incorpóreas e contrárias a que chamou de o um e o outro. Portanto, os números que expressam tais combinações são a própria essência da natureza. Dessa mistura surgem os quatro elementos que vão constituir, quando combinados entre si, todas as coisas da natureza. Porém, a realidade por detrás das aparências enganosas desses elementos - terra, ar, fogo e água - são as figuras geométricas perfeitas: tetraedro, cubo, octaedro e icosaedro" (VARGAS, op. cit., 1996, p. 250; grifo meu)

21 De acordo com Cornelli e Coelho, o problema da origem da matemática dedutiva sistemática grega está associada ao impacto, na matemática, da filosofia eleática, ou, mais precisamente, de sua dialética. A mudança, pois, da matemática "empírica" para a matemática "pura" está intimamente associada ao caráter idealista, anti-empírico da filosofia eleática e, sobretudo, da filosofia de Platão. Ver CORNELLI e COELHO, op. cit., 2007.

VARGAS, op. cit., 1996, p. 251. 
23 "Aristóteles insiste que as ideias não são separadas das coisas; existem enquanto relacionadas a elas, das quais são ideias. 0 que realmente existe são os entes individuais: aquilo que faz esses entes realmente representarem o que são. 0 ser desses entes representa a sua substância, com sua essência e seus acidentes. A essência é o que se diz da substância necessária para que ela permaneça sendo o que é; os acidentes são os predicados não-necessários para que 0 ente permaneça sendo o que é". (VARGAS, op. cit., 1996, p. 251)

24 MALUF, U. M. M. Geometrização do raciocínio em Aristóteles e Boole, linearidade e epistemologia. Arquivo Brasileiro de Psicologia, vol. 38, p. 65-71, 1985.

25 CORNELLI e COELHO, op. cit., 2007, p. 419

26 Trata-se da passagem daquilo que era entendido como filosofia da natureza para a concepção de ciência em seu sentido moderno. Transformação esta que se tornou evidente com o surgimento de instituições - as academias científicas - já no século XVI, na Itália. Outro modo de olhar para esse processo é a partir dos eventos que acompanharam a revolução científica, que representou também uma revolução social, ou, dito de outra maneira, as elaborações e atividades científicas entraram na dinâmica dos processos históricos. Se, por um lado, as navegações ocorridas no século XVI oferecem uma nova visão de mundo e ampliaram sua percepção com a valorização da prática, por outro lado as elaborações científicas transformaram a maneira de conceber 0 mundo, até então tido como um todo finito, harmônico e ordenado. Entre outros elementos e acontecimentos, como o desenvolvimento do capitalismo e a existência de uma lógica protestante, as navegações permitem questionamentos às antigas teorias, promovendo novas teorias, práticas, técnicas e visões de mundo, confluindo para o estabelecimento do que chamamos de ciência moderna.

27 Ver, para o que segue, KOYRÉ, Alexandre. Do Mundo Fechado ao Universo Infinito. Rio de Janeiro: Forense Universitária, 2010; IDEM. Estudos de História do Pensamento Científico. Rio de Janeiro: Forense Universitária, 2011.

280 destronamento do humano e a crise do antropocentrismo têm sido centro das reflexões de inúmeros pesquisadores, tratando-se de um tema contundente na contemporaneidade, desde os trabalhos inaugurais dos chamados estudos sociais da ciência e da tecnologia, mas também dos chamados estudos animais, multiespécies etc. (Alguns desses estudos são: HARAWAY, Donna. When species meet. Minneapolis: University of Minnesota Press, 2008; LATOUR, Bruno. Jamais fomos modernos. Rio de Janeiro: Editora 34, 1994.; IDEM. Reagregando o Social: uma introdução à teoria do ator-rede. Salvador: EDUFBA, Bauru, SP: EDUSC, 2012; TSING, Anna Lowenhaupt. The mushroom at the end of the world: on the possibility of life in capitalist ruins. Princeton: Princeton University Press, 2015; IDEM. Viver nas ruínas: paisagens multiespécies no Antropoceno. Brasília: IIEB Mil Folhas, 2019; COCCIA, Emanuele. A vida das plantas: uma metafísica da mistura. Florianópolis: Cultura e Barbárie, 2018; MARRAS, Stelio. Virada animal, virada humana: outro pacto. Scientiae Studia, vol. 12, p. 215-260, 2014; IDEM. Por uma antropologia do entre: reflexões sobre um novo e urgente descentramento do humano. Revista do Instituto de Estudos Brasileiros, n. 69, p. 250-266, 2018). Desde o século XX o falocentrismo também entra em crise, tornando-se cada vez mais insustentável.

29 A concepção de um universo intérmino corresponde a uma expressão de Deus, considerado por ele imperfeito. Nicolau de Cusa desenvolveu uma ideia de coincidência dos opostos no absoluto (que os transcende), ou seja, grande e pequeno constituem um par de conceitos opostos que só são válidos e significativos no reino da quantidade infinita, no reino do ser relativo, onde não existem "grandes" ou "pequenos", mas somente "maiores" ou "menores" que coincidem. Sua concepção expressa a falta de precisão e estabilidade no mundo criado. Ele promove a ideia de "douta ignorância", considerando que o mundo é determinado pelo lugar que o observador ocupa (e nenhum lugar é considerado privilegiado).

30 KOYRÉ, op. cit., 2010, p. 33.

31 Koyré considera que foi Descartes quem formulou claramente os princípios da nova ciência. Mas ele constrói uma narrativa interessada em descrever 0 processo cumulativo da história da ciência, que torna o universo infinito, ampliando a concepção de mundo, eliminando a metafísica da ciência, purificando-a e tornando-a objetiva e empírica. Nesse sentido, é uma narrativa que aposta no mito da ciência objetiva.

32 BURTT, Edwin. A. As bases metafísicas da ciência moderna. Brasília: Editora da UnB, 1983. 0 autor demonstra como a filosofia medieval era essencialmente religiosa, o universo era um lugar pequeno, finito - nesse sentido aproximando-se de Koyré - e a posição central era ocupada pelo homem. 0 mundo da natureza existia para ser desfrutado e conhecido pelo homem, que ocupava um lugar indestrutível. Em seguida, para a ciência moderna, o homem torna-se um produto casual e temporário, um espectador dos efeitos de uma natureza cega e sem propósito, como ressalta Burtt ao citar o filósofo contemporâneo Russell. Burtt considera que para compreender a principal corrente do pensamento não adiantaria recorrer à filosofia moderna, pois a metafísica moderna é em grande medida uma série de respostas à nova visão da relação entre o homem e a natureza. Ele reconhece ter ocorrido uma mudança radical na terminologia básica, aceita acriticamente pela filosofia moderna. Entretanto, entende que é preciso considerar que houve um desenvolvimento histórico que possibilitou as proposições modernas (que tem sido esquecido e negligenciado), por isso sua proposta é uma pesquisa histórica de análise da filosofia moderna em seus primórdios.

33 Burtt e Koyré divergem sobremaneira a esse respeito. Para Koyré, Isaac Newton era um cientista profissional, embora a ciência em sua época ainda fosse chamada de "filosofia natural" e concebida como tal. Ou seja, Koyré transforma Newton em cientista profissional, considerando que este faz poucos e reticentes pronunciamentos metafísicos. Ainda que sua física ou "filosofia natural" não pudesse ser dissociada de conceitos de tempo e espaço absolutos, Koyré considera que Newton se ocupava da filosofia apenas na medida em que necessitava dela para estabelecer os fundamentos de sua investigação matemática da natureza, investigação vista como empírica e supostamente positiva. Nesse sentido Koyré parece apartar a física de Newton de sua metafísica, tornando-o um cientista profissional, ou seja, um cientista moderno. A partir daí estabelece-se quem poderia falar sobre tempo e a quem caberia tratar de duração. Os "filósofos naturais" são transformados e divididos em cientistas e filósofos, cada um devendo se ocupar de suas questões específicas. Ainda que desenvolvesse conceitos metafísicos é a física de Newton que interessa a Koyré, bem como sua investigação matemática da natureza. Ao elaborar a concepção do caráter absoluto da rotação, oposta à translação retilínea, por exemplo, para Koyré Newton consegue torná-la acessível ao conhecimento empírico, garantindo seu papel e lugar como um conceito fundamental da ciência.

34 É possível, no entanto, questionar: ao falar sobre temas como a natureza do espaço, do tempo e da matéria e as relações do homem com os objetos de seu conhecimento Newton oferece respostas metafísicas? Ou transforma questões metafísicas em questões científicas, já que atribui novos significados a velhos termos? Será que Newton apresenta um trabalho com bases metafísicas para o avanço matemático ou transforma os fenômenos da filosofia natural em fenômenos redutíveis ao tratamento matemático? E mais: considerar as bases metafísicas do pensamento resolve a dissolução ocorrida na ciência moderna (no sentido de romper com a crença científica e seu mito de ciência objetiva e empírica)?

35 COCCIA, op. cit., 2018, p. 18.

36 A pesquisadora do campo de Ciência, Tecnologia e Sociedade Anne Pollock propõe, ao investigar o caráter hidráulico do coração, não apenas seu papel supostamente ativo, mas o reconhecimento de sua passividade como fundamental para a sua atuação. Segundo Pollock, se por um lado o coração é descrito como um órgão muscular que opera de acordo com um modelo fálico, ativo, que bombeia sangue para todo o corpo; por outro lado ele deve ser caracterizado por sua receptividade e passividade, que permite que o coração seja um órgão que não apenas distribui o fluido, como o pênis, mas também 
o receba, possibilitando que a circulação ocorra. É por esvaziar-se e abrir espaço que os ventrículos permitem que o sangue adentre sua câmara e possa ser impulsionado. Desde a emergência da concepção da circulação sanguínea, atribuída a William Harvey (1578-1657), o caráter receptivo do coração foi obscurecido por seu argumento a respeito da atuação do sangue para a circulação, impulsionado pelo coração, visto, portanto, como ativo, mas não no sentido que quer atribuir Pollock: ativo em sua passividade, cujo impulso seria possibilitado pela abertura de espaço. Ver POLLOCK, Anne. Heart feminism. Catalyst. Feminism, Theory, Technoscience, vol. 1, p. 1-30, 2015.

37 DESPRET, Vinciane. Culture and gender do not dissolve into how scientists 'read' nature: Thelma Rowell's Heterodoxy. In: HARTAMAN, 0.; FRIEDRICH, M. (eds.). Rebels of life: iconoclastic biologists in the twentieth century. New Haven: Yale University Press, 2008, p. 3-4.

38 IDEM, p. 3-4: "Numerous observers among primatologists and science studies scholars have suggested that women observed differently. For some, womens' patience makes them ideal observers. The well-known paleoanthropologist, Louis Leakey, deliberately chose to send women - Jane Goodall in the early 1960's, and later, Diane Fossey and Biruté Galikas - into the field because he assumed that they were better observers of primates and would be more emotionally connected to their subjects, the animals. This characteristic has been largely supported by what has been called the 'National Geographic effect,' which 'had done much to create the myth that primatology is a type of mothering activity.' This conception gives rise to the idea that women are better observers of animals because they have a special relationship with nature".

39 Passo a passo é um método proposto por um importante pesquisador do campo dos corações artificiais, Yukihiko Nosé, baseado na progressão e aperfeiçoamento do projeto por meio de resultados preliminares. Isso significa que, à medida em que avança nas fases da pesquisa, o método passo a passo pode demandar que o pesquisador retorne ao estágio anterior para refaze-lo. Segundo a pesquisadora a vantagem de adequar a forma da aleta a uma proporção ideal é poder escapar dos resultados contraditórios que o método passo a passo pode gerar, na medida em que o projeto final se torna diferente do original.

40 SERRES, op. cit., 1990.

(Artigo recebido em Janeiro de 2019. Aceito para publicação em Junho de 2019)] 